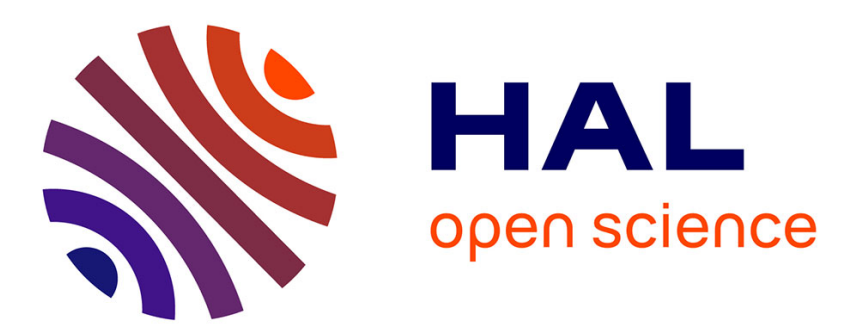

\title{
Effects of Storage Conditions, Total Solids Content and Silage Additives on Fermentation Profiles and Methane Preservation of Cattle Manure Before Anaerobic Digestion
}

\author{
Ruben Teixeira Franco, Pierre Buffière, Rémy Bayard
}

\section{To cite this version:}

Ruben Teixeira Franco, Pierre Buffière, Rémy Bayard. Effects of Storage Conditions, Total Solids Content and Silage Additives on Fermentation Profiles and Methane Preservation of Cattle Manure Before Anaerobic Digestion. Waste and Biomass Valorization, 2018, 9 (12), pp.2307-2317. 10.1007/s12649-

018-0255-4 . hal-01942683

\section{HAL Id: hal-01942683 \\ https://hal.science/hal-01942683}

Submitted on 7 Jan 2019

HAL is a multi-disciplinary open access archive for the deposit and dissemination of scientific research documents, whether they are published or not. The documents may come from teaching and research institutions in France or abroad, or from public or private research centers.
L'archive ouverte pluridisciplinaire HAL, est destinée au dépôt et à la diffusion de documents scientifiques de niveau recherche, publiés ou non, émanant des établissements d'enseignement et de recherche français ou étrangers, des laboratoires publics ou privés. 


\title{
Effects of storage conditions, total solids content and silage additives on fermentation profiles and methane preservation of cattle manure before anaerobic digestion
}

\author{
Ruben Teixeira Franco, Pierre Buffière, Rémy Bayard ${ }^{1}$ \\ Université de Lyon, INSA Lyon, DEEP Laboratory, EA7429, F-69621 Villeurbanne cedex,
} France

\begin{abstract}
The impacts of storage conditions, total solids content and silage additives were investigated at laboratory scale for cattle manure during up to 120 days. Wheat straw was used as co-substrate in the study of the effects of total solids content. Glucose and starch were used as model molecules of sugar-rich co-substrates. Single-handedly cattle manure lost $37 \%$ of its original methane potential after 120 days of anaerobic storage. This was essentially caused by the low total solids content and by the absence of water soluble carbohydrates in the feedstock. Wheat straw addition decreased moisture content and enabled cattle manure stabilization for a $\mathrm{pH}$ of 6.0. In contrast, extensive heterofermentative lactic acid bacteria fermentation occurred during co-ensiling with glucose and the $\mathrm{pH}$ quickly dropped to values below 4.0. Starch was used as substrate for fermentation but its hydrolysis limited bacterial activity and acidification. Finally, all the three co-substrates led to minimal methane potential losses after 120 days of storage. Coensiling will improve the energy efficiency of agricultural biogas plants that use stored cattle manure as feedstock.
\end{abstract}

Keywords: Cattle manure; Additives; Storage; Ensiling; Anaerobic digestion; Methane potential

\footnotetext{
${ }^{1}$ Corresponding author. Tel.: +33(0) 472438753

E-mail addresses: ruben.teixeirafranco@insa-lyon.fr (R. Teixeira Franco), pierre.buffiere@insa-lyon.fr (P. Buffière), remy.bayard@insa-lyon.fr (R. Bayard)
} 


\section{Introduction}

The growth of the agricultural biogas sector in France is promoting the energy valorisation of livestock manure. According to the French Environment and Energy Management Agency, cattle manure potential for biogas production in France may reach around $183 \mathrm{Mt}$ per year by 2030, which could represent an annual energy potential of 40500 GWh [1].

Despite this expected use as a source of energy, cattle manure is still typically treated as a waste. Indeed, biogas plant operators take very few precautions during its handling and management. Like other agricultural wastes or crops, cattle manure is not available on constant amounts all year round. For instance, during winter months, cattle is housed indoors, while as the weather gets warmer and the grass starts to grow cattle normally goes into the fields and manure is not recovered for anaerobic digestion (AD). Therefore, in order to ensure a constant supply of raw material for AD plants, cattle manure must be stored before use, from few days up to several weeks. The use of open-air storage facilities is the most common practice for this type of feedstock. Yet, the contact with air leads to odour and ammonia emissions [2], biomass damage and energy losses. As reported in a previous work [3], losses of methane potential for cattle manure may ascend to more than $70 \%$ after 120 days in presence of air, which can be mitigated through confined storage.

Ensiling is a preservation process that depends on the natural fermentation of biomass under confined conditions to minimize the contact with air. It can be divided in four successive stages $[4,5]$. First, aerobic biomass respiration occurs during several hours, converting water-soluble carbohydrates (WSC) in carbon dioxide, water and releasing energy. Once oxygen is depleted, microorganisms capable of anaerobic growth will compete for the substrate. Under suitable conditions, lactic acid bacteria ( $\mathrm{LAB}$ ), naturally present in wet biomass, will produce lactate from available sugars, decreasing the $\mathrm{pH}$ value to around 4.0. The combination of an anaerobic and acidic environment will stabilize the feedstock and impede further substantial microbial activity until the feed-out. After unloading the silo, aerobic microorganisms are reactivated, which may spoil the silage if prompt AD feeding is not carried out. This storage method is considered as the most efficient way to preserve wet biomass [4] and leads to full energy conservation for 
prolonged durations [6-11]. However, substantial losses will occur during ensiling of inadequate feedstocks, such as cattle manure. Indeed, $46 \%$ of fresh cattle manure's biochemical methane potential (BMP) may be lost after 120 days of anaerobic storage [3]. Lack of easily fermentable sugars and high moisture content are some of the proposed causes for the ensiling failure.

Co-ensiling of cattle manure with other substrates has been a promising approach to limit the energy loss during storage. Wheat straw addition to fresh manure stimulated a conservation of more than $86 \%$ of BMP after 120 days of ensiling [3]. Mechanisms related to the increase of total solids (TS) content and reduction of the buffering capacity were proposed to explain this improvement. However, wheat straw addition may not be an asset for the preservation of all types of manure. In another experiment, more than $60 \%$ of BMP was lost after long-term coensiling of manure with straw [12]. We suggested that this was caused by a substantial methanogenic activity in the cattle manure. The most impressive results were obtained by using direct and indirect sources of acidification. In particular, co-storage of fresh cattle manure with addition of both wheat straw and high concentration of glucose led to full conservation of methane potential even after 120 days.

In the present work, the objective was to deepen the knowledge about the best co-storage practices of cattle manure before AD. The effects of ensiling, water availability and silage additives were evaluated through storage assays at laboratory scale with cattle manure and several co-substrates for up to 120 days. The impact of TS content was studied by adding wheat straw. Moreover, glucose and starch were used as model molecules of fermentation stimulants for the co-ensiling assays. Glucose simulates the use of a WSC-rich co-substrate and starch simulates the use of a starch-rich co-substrate in real application. The experimental approach enabled to monitor fermentation profiles, fibres structure and conservation of both organic matter and methane potential during ensiling.

\section{Material and methods}

\subsection{Feedstock}

Fresh cattle manure was collected from an agricultural site near Lyon (France) and stored at $4{ }^{\circ} \mathrm{C}$ before use (for 2 days). In this farm, dairy cattle was housed indoors in free stalls, fed with 
a mixture of maize/grass silage, alfalfa and cull potatoes, and manure was mechanically removed several times a day. Besides storage of single-handedly cattle manure with TS content of $12 \%$ (CM12\%), co-ensiling assays were performed with several co-substrates: wheat straw (10 cm maximum length), anhydrous glucose (D-(+)-glucose for analysis, Chimie-Plus, France) and starch (pure soluble starch, Chimie-Plus, France). Glucose was solved in water before addition to cattle manure in order to keep a constant TS content of the feedstock before and after glucose addition. Starch was directly added in powder and mixed with the feedstock, due to its low solubility in water. The amount of co-substrates was chosen according to our previous results on cattle manure storage $[3,12]$.

Initial feedstock conditions are summarized in Table 1. CM16\% and CM21\% were obtained by adding 70 and $153 \mathrm{~g}$ of straw per $\mathrm{kg}$ of fresh cattle manure (CM12\%). CM12\%G, CM16\%G and $\mathrm{CM} 21 \% \mathrm{G}$ were obtained by adding $100 \mathrm{~g}$ of glucose per $\mathrm{kg}$ of $\mathrm{CM} 12 \%, \mathrm{CM} 16 \%$ and $\mathrm{CM} 21 \%$, respectively. Finally, CM16\%S was obtained by adding $53 \mathrm{~g}$ of starch per $\mathrm{kg}$ of $\mathrm{CM} 16 \%$.

\subsection{Experimental approach}

Laboratory trials were performed in $3.5 \mathrm{~L}$ airtight round plastic storage drums. In order to enable the output of the gas produced and at the same time minimizing headspace, silos were filled up to $2.55 \mathrm{~L}$ with raw material at packing density of $0.7 \mathrm{~kg} / \mathrm{L}$, the remaining volume being filled with gravel, using a geotextile membrane to separate it from biomass. Proper plastic lid and rubber ring were used for silo sealing and its airtightness was reinforced with silicone sealant. Then, silos were weighed and placed in a controlled-temperature room at $25 \pm 2{ }^{\circ} \mathrm{C}$. All feedstocks were stored for 30 and 120 days. Co-ensiling with glucose/starch was additionally tested for 7 and 15 days of ensiling. A total of 22 ensiling assays were performed.

\subsection{Chemical analysis}

For each sample time, one silo per tested condition was sacrificed. It was opened and weighed, biomass was homogenized and two samples were taken. One was used for direct analyses on the crude material and the other one was mixed with water in order to get two fractions: a watersoluble phase and a particulate phase. This leaching test was performed with a 10:1 water/dry matter ratio during $2 \mathrm{~h}$ under constant bottle rotation. Phase separation was achieved by 
centrifugation ( $5000 \mathrm{G} ; 10 \mathrm{~min}$ ) followed by $0.7 \mu \mathrm{m}$ particle size filtration. Finally, the particulate phase was dried at $70^{\circ} \mathrm{C}$ until constant weight and ground at $2 \mathrm{~mm}$ theoretical length. Crude material/water-soluble and particulate samples were stored at $4{ }^{\circ} \mathrm{C}$ and $-20^{\circ} \mathrm{C}$, respectively, until use.

Crude material was analysed for its TS content, volatile solids (VS) content and BMP. For the water-soluble phase, besides TS/VS content and BMP, pH, WSC, volatile fatty acids (VFA), ethanol, total Kjeldahl nitrogen (TKN) and ammonia nitrogen $\left(\mathrm{NH}_{3}-\mathrm{N}\right)$ fractions were determined. Particulate solid was analysed for its TS/VS, TKN and cell wall constituents content.

TS was measured by oven drying at $105^{\circ} \mathrm{C}$ during $24 \mathrm{~h}$ and VS was subsequently burned for 2 h at $550^{\circ} \mathrm{C}$. Since TS/VS contents are underestimated due to the loss of volatile compounds during the drying tests [7], the measures were corrected using the volatilization coefficients at $100^{\circ} \mathrm{C}$ suggested by Porter and Murray [13]. pH was measured by a Consort C3020 device with a SP10B pH-electrode. WSC and lactic acid (LA) contents were determined with high performance liquid chromatography (LC Module 1 plus, Waters) equipped with a Supelcogel ${ }^{\mathrm{TM}}$ C- $610 \mathrm{H}$ column ( $300 \times 7.8 \mathrm{~mm}$, Sigma-Aldrich), both refractive index (RID) and UV detectors and operating with $\mathrm{H}_{3} \mathrm{PO}_{4} 0.1 \% \mathrm{v}$ as solvent (flow rate of $0.5 \mathrm{~mL} / \mathrm{min}$ ). WSC content was estimated as the sum of glucose, xylose, galactose, mannose, arabinose and cellobiose and was determined using the UV detector $(210 \mathrm{~nm})$. Lactic acid and formic acid contents were obtained with the RID detector. Ethanol and Acetic (AA), propionic, butyric $(B A)$, valeric and caproic acids content were analysed using gas chromatography (Shimadzu Corp.) equipped with a HP-FFAP fused silica capillary column (30 m x $0.25 \mathrm{~mm}$, Agilent Technologies), a flame ionization detector and using $\mathrm{H}_{2}$ as carrier gas. Total VFA was calculated as the sum of lactic, formic, acetic, propionic, butyric, valeric and caproic acids. Neutral detergent fibre (NDF), acid detergent fibre (ADF) and acid detergent lignin (ADL) were analysed through Van Soest and Wine [14] modified extractions method based on FD U44-162 standard [15]. Hemicellulose content was calculated as NDF minus ADF; cellulose as ADF minus ADL and; lignin as approximatively equal to $\mathrm{ADL}$. TKN and $\mathrm{NH}_{3}-\mathrm{N}$ were determined through the procedure described in the NF EN 25663 standard [16]. 


\subsection{Biochemical methane potential tests}

Batch anaerobic digestion tests were performed for crude material and water-soluble phase samples. Tests were conducted in a temperate room at $35^{\circ} \mathrm{C}$ using glass vessels of $2 \mathrm{~L}$ for crude material and $0.1 \mathrm{~L}$ for water-soluble phase. Vessels were filled with $5 \mathrm{~g}$ VS of sample, inoculum so as to keep a substrate/inoculum VS ratio of 0.5 and a certain volume of a mineral solution to achieve $60 \%$ of the total volume of the vessel. The inoculum used (TS 2.0-3.0\%wt; VS 1.4-2.2\%wt) was a digested sludge originating from the wastewater treatment plant of La Feyssine, Lyon, France. The sludge used met the criteria for a good inoculum quality (e.g. pH, VFA, $\mathrm{NH}^{+}$) suggested by the international task group on the harmonization of BMP protocols [17]. The mineral solution, which contains essential elements to microbial growth and also gives the solution a buffer able to control any $\mathrm{pH}$ adjustments, was prepared according to the recommendations of ISO 11734:1995 standard. Once filled, reactors were purged with a $\mathrm{N}_{2} / \mathrm{CO}_{2}$ mixture $(80 / 20 \% \mathrm{v})$ for about 5 minutes, sealed and equilibrated at $35^{\circ} \mathrm{C}$. Blanks with only inoculum and mineral solution were performed for each batch series in order to correct the BMP from residual methane production of the inoculum. All tests were performed in triplicates.

Biogas production was determined by pressure measurement using a Digitron precision manometer. Biogas was released when the pressure exceeded $1200 \mathrm{hPa}$. Gas composition was analysed using an Agilent 3000 micro gas chromatography with thermal conductivity detector (GC-TCD). Molsieve 5A (14 m length; pore size: $5 \AA$ ) and PoraPlot A (10 m length; $0.320 \mathrm{~mm}$ ID) columns were used as stationary phases for GC-TCD, with Argon and Helium as carrier gases, respectively. Biogas production and composition were analysed at least 7 times during the incubation and BMP was considered achieved when daily biogas production represented less than $1 \%$ of the total biogas volume produced. The BMP tests followed the recommendations provided by Holliger et al. [17].

\section{Results and discussion}

\subsection{Feedstock characterisation}

The data presented in Table 1 shows that fresh cattle manure had a low TS content (11.6\%). This can cause difficulties in filling and compacting a bunker silo due to liquid seepage. In such 
conditions, storage of manure in anaerobic tanks should be preferable. In addition, the bacterial activity should be high in anaerobic conditions due to the low TS content, which may lead to energy losses. The interest of wheat straw addition was thus to increase the TS content $(16.3 \%$ and $20.9 \%$ after wheat straw addition). For glucose trials, the addition of co-substrate in solution kept the organic matter content stable before ensiling. On the opposite, starch was used in the form of solid compound and the TS content was $20.4 \%$ after addition.

Fresh cattle manure contained no WSC, Table 2. This was an undesired feature, since WSC are the most accessible substrates for lactic acid fermentation. Only raw materials with glucose addition had a significant initial WSC content, between $35 \%$ and $53 \%$ (VS basis). These amounts were significantly higher than the ones found in the literature for feedstocks that were successfully acidified during ensiling $[8,18-22]$. Concerning CM16\%S condition, no WSC was observed in the initial sample, since starch is not a water-soluble molecule. However, the theoretical content of starch should be $27 \%$ VS. Considering the expected breakdown of the glycosidic bonds of starch and its subsequent fermentation in the early days of storage, the amount of starch used should be enough to ensure a proper acidification. Therefore, lactic acid fermentation for this condition rather depend on the rate of starch degradation than on starch amount. Wheat straw alone did not bring any additional WSC, due to the lignocellulosic structure of wheat straw, which was confirmed by the increase of the structural carbohydrates content in CM16\% and CM21\% feedstock, Table 3.

The use of co-substrates had few impact on the initial pH, which ranged from 7.4 to 8.1. However, these values were quite higher than that of crops, such as maize (from 5.5 to 5.8 [23, 24]) or grass ( $\mathrm{pH}=6.0$ [25]). Notwithstanding, there was already an important amount of volatile fatty acids in the fresh cattle manure (5.0\%VS). Certainly, cattle manure has a strong basic buffering capacity and an important production of organic acids should occur during ensiling to reach the same acidity than crop silage.

Finally, total Kjeldahl nitrogen content decreased with the addition of co-substrates, due to the absence of nitrogen compounds in the additives. Therefore, nitrogen structure was identical for all conditions. Moreover, it is important to notice that ammonia nitrogen content was quite high 
in feedstocks (15-22\%TKN). This might cause substantial ammonia emissions if $\mathrm{pH}$ moves toward alkalinity during the storage period $[3,12]$.

\subsection{Effects of storage conditions on biomass preservation}

\subsubsection{Fermentation profiles}

Fresh cattle manure (CM12\%) was acidified during the first 30 days of storage, with a pH decrease from 7.7 to 6.1. This was due to VFA accumulation, which reached around $14 \% \mathrm{VS}_{\text {added }}$ after 30 days. However, fermentation profiles of CM12\% shifted for longer storage periods: the $\mathrm{pH}$ increased to 7.8 and organic acids concentration decreased to $8.3 \% \mathrm{VS}_{\text {added }}$ after 120 days. Considering measured VS losses, this represented a VFA degradation of $53 \%$ in the last 90 days. These two distinct fermentation profiles were attributed the lack of WSC, high alkalinity and low TS content. In other words, without WSC in raw material, the degrading bacteria must hydrolyse carbohydrates in order to produce VFA. Consequently, acidification will be slower and lactic acid may only be an intermediate in the production of other mixed organic acids. This phenomenon is well known and even implemented in anaerobic digestion models due to the fast lactate uptake at neutral $\mathrm{pH}$ [26]. The major component of VFA was acetic acid, with other low concentrations of butyric, propionic, valeric and caproic acid. Since these acids are weaker than lactic acid, $\mathrm{pH}$ drop for $\mathrm{CM} 12 \%$ was lower than in lactate silages. Thereupon, due to the relatively high $\mathrm{pH}$ and water availability, the methanogenic population must have proliferated, leading to VFA consumption in the last months.

Wheat straw addition to cattle manure led to $\mathrm{pH}$ stabilization in the long term. For $\mathrm{CM} 16 \%, \mathrm{pH}$ decreased from 8.1 to 5.9 in the first 30 days and did not vary by the end of the experiment. For $\mathrm{CM} 21 \%, \mathrm{pH}$ was around 6.0 in the last 90 days of ensiling. This was due to organic acids accumulation during the 120 days: VFA content was 6.7-9.0\%VS added after 30 days and 9.3$11.7 \% \mathrm{VS}_{\text {added }}$ at the end. This stabilization after wheat straw addition is probably due to the decrease of water availability. Indeed, most bacteria have lower activity at higher TS levels [4, 25, 27-29]. Therefore, the TS increase caused by wheat straw addition may have been enough to prevent methanogenic activity for a $\mathrm{pH}$ level around 6.0 , as already observed in a previous experiment [3]. 
The VFA mix in CM16\% and CM21\% was mainly composed of acetic and butyric acids. In anaerobic processes, the production of these VFA includes other side-products, such as $\mathrm{H}_{2}$ [26]. Therefore, even if all the degraded carbohydrates were converted into VFA, some energy loss should have occurred for $\mathrm{CM} 16 \%$ and $\mathrm{CM}_{2} 1 \%$ with $\mathrm{H}_{2}$ production.

Unlike wheat straw, glucose addition to cattle manure encouraged a strong biomass acidification in the early days of ensiling: after 7 days, $\mathrm{pH}$ was $3.8,4.4$ and 4.6 for $\mathrm{CM} 12 \% \mathrm{G}$, CM16\%G and CM21\%G, respectively (Table 2). This was a result of an abundant lactic acid production, which represented already $12.9-17.1 \% V_{\text {added }}$ after 7 days of co-ensiling. After that, lactic acid production and $\mathrm{pH}$ drop continued until full consumption of WSC. After 30 days, $\mathrm{pH}$ was 3.6-3.8. This demonstrates that $L A B$ was present in cattle manure and that only the lack of substrate hindered its acidification. Moreover, lactate production was higher at low TS contents, showing that $L A B$ are also sensitive to water availability. In the last 90 days, minimal $\mathrm{pH}$ modifications occurred for $\mathrm{CM} 12 \% \mathrm{G}$ and $\mathrm{CM} 16 \% \mathrm{G}$. On the opposite, the $\mathrm{pH}$ of $\mathrm{CM} 21 \% \mathrm{G}$ increased to 5.0 after 120 days, concomitantly with lactate consumption and butyrate production. This indicates clostridial fermentation, which is a mechanism that occurs in poor quality silages. However, this was unexpected since clostridial activity should be delayed with the decrease of water availability $[4,30]$.

Besides lactic acid, ethanol was found in substantial amounts for co-ensiling with glucose: 4.6$5.8 \% V_{\text {Vadded }}$ after 7 days, $10.2-16.6 \% V_{\text {Sadded }}$ after 30 days. This type of alcoholic fermentation was not recorded in our former work [12]. In fact, under ensiling conditions, LAB can ferment a wide range of substrates by several pathways [4]. Using glucose as substrate, LAB can be labelled in two main groups: homofermentative (Ho LAB) and heterofermentative (He LAB). Ho LAB almost exclusively produce lactic acid from glucose, while He LAB convert glucose in lactic acid, ethanol, carbon dioxide and water. Much probably, LAB populations significantly vary among cattle manures. In the present case study, mostly He LAB population was present, since extensive ethanol production was observed. Furthermore, the differences in LAB populations will have a significant effect on the rate of WSC conversion during ensiling. Indeed, if He LAB fermentation is carried out, glucose consumption should be two times higher to achieve the same level of acidity than Ho LAB fermentation, since ethanol is not an hydrogen donor $\left(\mathrm{pK}_{\mathrm{a}}=\right.$ 
16). This also explains why WSC was consumed much faster in these assays (He LAB fermentation) than in our previous work.

Starch addition (CM16\%S) also improved biomass acidification of cattle manure with straw. Indeed, the pH was already 5.5 after 7 days and 4.8 after 120 days. This suggests that starch was used as substrate for VFA production. However, fermentation degrees of CM16\%S were lower than with glucose. After 7 days, VFA content was $8.2 \%$ VSadded for CM16\%S, while it was $16.5 \% \mathrm{VS}_{\text {added }}$ and $14.9 \% \mathrm{VS}_{\text {added }}$ for $\mathrm{CM} 16 \% \mathrm{G}$ and $\mathrm{CM} 21 \% \mathrm{G}$, respectively. Moreover, VFA was mainly composed of acetic and butyric acids. Lactate was only detected in the first 7 days of CM16\%S (1.3\%VS added). This shows that starch hydrolysis limited the rate of lactic acid production. Furthermore, ethanol was only present in trace concentrations for CM16\%S condition, since He LAB fermentation is favoured at low $\mathrm{pH}$ conditions [31].

Finally, we see from Table 2 that $\mathrm{NH}_{3}-\mathrm{N}$ concentration correlates with the $\mathrm{pH}$. Indeed, there was no significant modification of ammonia-nitrogen content with $\mathrm{pH}$ lower than 5.5 after 7 days (glucose and starch co-silages). In contrast, $\mathrm{NH}_{3}-\mathrm{N}$ substantially increased during storage of cattle manure without silage additives. This was especially true for $\mathrm{CM} 12 \%$, for which ammonia was initially $20.8 \%$ TKN and $41.7 \%$ TKN after 120 days. This confirms that proteolysis rather occurs at high $\mathrm{pH}[4,32,33]$. Proteolysis also leads to side-products, such as VFA, $\mathrm{CO}_{2}$ and $\mathrm{H}_{2}$ [26], therefore increasing energy losses during storage. Under all conditions however, even if nitrogenous compounds degradation took place, no ammonia emissions took place: the TKN content did not decrease, since ammonium ion was the predominant species at $\mathrm{pH}$ below the $\mathrm{pK}_{\mathrm{a}}$ of $\mathrm{NH}_{4}+\mathrm{NH}_{3}(9.25)$.

\subsubsection{Structural carbohydrates}

A substantial degradation of structural carbohydrates was observed for all conditions (Table 3). According to Dewar et al. [34] and McDonald et al. [4], conversion of these polymers during storage are due to enzyme activity or acid hydrolysis by organic acids produced in the course of ensiling.

The higher breakdown degrees of structural carbohydrates were found for $\mathrm{CM} 12 \%, \mathrm{CM} 16 \%$ and $\mathrm{CM} 21 \%$. After 30 days, around $18-24 \%$ of the sum of original (hemi-) cellulosic compounds 
were lost. After 120 days, the breakdown reached $40 \%$ for $\mathrm{CM} 12 \%, 30 \%$ for $\mathrm{CM} 16 \%$ and $29 \%$ for $\mathrm{CM} 21 \%$. This suggests that some WSC were released by partial hydrolysis of carbohydrates and used for VFA production in the long term. Since an acid $\mathrm{pH}$ was not detected, breakdown of (hemi-) celluloses was probably due to enzyme activity. Furthermore, the consumption of structural carbohydrates for $\mathrm{CM} 12 \%$ after 120 days was higher than for the other ensiling conditions. In the same time, a partial degradation of VFA was observed, suggesting an important loss of organic matter for this feedstock after long term storage.

Glucose addition to cattle manure restricted the degradation of structural carbohydrates. Indeed, after 120 days, conversion of initial complex sugars was $15 \%$ for $\mathrm{CM} 12 \% \mathrm{G}, 23 \%$ for CM16\%G and $11 \%$ for CM21\%G. The breakdown products were likely used as substrate for lactate production, since no accumulation of WSC occurred. However, co-silages with glucose led to low $\mathrm{pH}$ (below 4.0). Therefore, the degradation of hemicelluloses and cellulose for these conditions may have occurred through acid hydrolysis.

The results of fibres analysis for co-ensiling with starch indicates extensive plant cell wall degradation during the first week of storage, corresponding to around $21 \%$ of the particulate carbohydrates. This is a high value compared to co-ensiling with glucose after one week, or even to $\mathrm{CM} 16 \%$ and $\mathrm{CM} 21 \%$ after 30 days. In fact, this corresponded to a period in which starch was hydrolysed and fermented into VFA. Consequently, it is possible that loss of nonsoluble carbohydrates was partially due to the breakdown of starch and not of (hemi-) cellulosic compounds. In fact, Van Soest et al. [35] stated that starch interfere with the analysis of cell wall constituents and increase the value of structural sugars. Therefore, further interpretation on the cell wall composition of co-ensiling with starch should be avoided.

\subsubsection{Conservation of organic matter}

The extension of fermentation and stability of silage had a significant effect on the conservation of organic matter over the storage period, Fig. 1. It was during storage of single-handedly cattle manure (CM12\%) that the largest VS degradation occurred: VS losses were in average $6.5 \%$ per month of storage. This high rate of organic matter spoilage is due to the low TS content of raw material and to the subsequent rapid loss of structural carbohydrates. 
Reduction of water availability with wheat straw had a positive impact on the organic matter conservation, especially in the long term. For both $\mathrm{CM} 16 \%$ and $\mathrm{CM} 21 \%$, VS losses were minimal and mostly occurred during the 30 days of storage (Fig. 1a). After 120 days, more than $94 \%$ of organic matter was conserved. This shows the importance of a high TS content on the conservation of organic matter while using feedstocks without easily accessible substrate for fermentation. In this case, VS losses are probably due to the formation of side-products during fermentation, such as $\mathrm{CO}_{2}$ and $\mathrm{H}_{2}$.

Likewise, for co-silages with glucose addition, losses of organic matter principally occurred in the early days (Fig. 1b). However, the range of degradation was higher than in co-ensiling with wheat straw. After 15 days, original VS conservation reached $86 \%$ for $\mathrm{CM} 12 \% \mathrm{G}$ and $89 \%$ for both $\mathrm{CM} 16 \% \mathrm{G}$ and $\mathrm{CM} 21 \% \mathrm{G}$. These values are coherent with the amounts of $\mathrm{CO}_{2}$ and $\mathrm{H}_{2} \mathrm{O}$ that would be produced if all original WSC were fermented by He LAB. Therefore, we expected limited energy losses during this period. In addition, from day 15 to the end of the experiment, no further organic matter degradation occurred for $\mathrm{CM} 12 \% \mathrm{G}$ and $\mathrm{CM} 16 \% \mathrm{G}$. On the opposite, VS conservation of CM21\%G decreased from $89 \%$ after 30 days to $84 \%$ at the end of storage. This should be related to the secondary fermentation that happened for $\mathrm{CM} 21 \% \mathrm{G}$ during this period.

Ensiling of cattle manure with starch (CM16\%S) can be considered as an intermediate condition in terms of VS preservation. On the one hand, organic matter of CM16\%S was less degraded than the co-storage with glucose. This is explained by the weaker He LAB activity for the raw material with starch. On the other hand, for CM16\%S, VS conversion was higher than during ensiling without fermentation stimulants. This supports the assumption that starch is used as additional substrate for biomass acidification. Moreover, as for the remaining stable silages, during storage of $\mathrm{CM} 16 \% \mathrm{~S}$ the major conversion of organic matter occurred in the 30 days: conservation of VS was $94 \%$ after 30 days and $91 \%$ at the end.

\subsection{Effects of storage conditions on methane production during $A D$}

\subsubsection{BMP evolution}


BMP values based on VS added are presented on Table 4. The BMP data was analysed by oneway ANOVA followed by the Fisher test $(P<0.05)$. Any difference larger than the Least Significant Difference, $12 \mathrm{LsTP} \mathrm{kgVS}_{\text {added/original }}{ }^{-1}$, was considered a significant result. It is important to mention that BMP values for samples with 30 days of ensiling were quite lower than expected, which may be due to a reactivity issue of the inoculum used for the BMP tests. Therefore, these data were only used for qualitative considerations.

Regarding feedstocks, wheat straw addition decreased the BMP of fresh cattle manure from 257 Lstp kgVS $_{\text {added }^{-1}}$ to 232 LstP kgVS $_{\text {added }}{ }^{-1}$ for CM16\% and 215 Lstp kgVS $_{\text {added }^{-1}}$ for CM21\%. This evidences the low biodegradability of wheat straw in anaerobic digestion. On the opposite, BMP of raw material increased with the use of glucose: $319 \mathrm{LsTP} \mathrm{kgVS}_{\text {added }}{ }^{-1}$ for CM12\%G, 286 LstP kgVS added ${ }^{-1}$ for CM16\%G and $271 \mathrm{LsTP}_{\text {kgVS }}$ added $^{-1}$ for CM21\%G. This is in line with the theoretical methane yield of glucose (373 LstP kgVSadded $\left.{ }^{-1}\right)$ and the amounts of co-substrate used for the three experiments. Since pure starch also has an important BMP, $352 \pm 33$ LsTP $\mathrm{kgVS}_{\text {added }^{-1}}$ [36], the same trend was expected for the feedstock with starch addition. However, CM16\%S had a BMP before storage of $236 \mathrm{LsTP} \mathrm{kgVS}_{\text {added }^{-1}}$ which was similar to the raw material without starch addition. Therefore, this indicates that starch was not fully degraded during the BMP test with cattle manure. The reasons for this are still unclear, even if unequal BMP for commercial starch were already reported [36].

Anaerobic storage had a significant negative impact on BMP related to VSadded of singlehandedly cattle manure. After 120 days, $16 \%$ of BMPvsadded was lost for CM12\%. This indicates a loss of global biochemical accessibility, related to the damage of both structural carbohydrates and organic acids in the last 90 days of ensiling. The biomass conservation was improved by storing cattle manure with wheat straw. In fact, for both $\mathrm{CM} 16 \%$ and $\mathrm{CM} 21 \%$, methane potential based on VS added was stable after 120 days (non-significant BMP variation during storage), which also means that the conversion of cellulosic compounds did not have a significant impact on the accessibility of biomass.

In the contrary, BMP related to VSadded significantly increased during ensiling with fermentation stimulants. On the one hand, this may be related to the accumulation of organic acids and 
alcohols over the storage period [6]. As a matter of fact, some of these compounds have higher BMP by mass unit of VS than the substrates used for their production (since carbon is lost under the form of $\mathrm{CO}_{2}$ during this process). This is the case of ethanol (BMP $=730$ LsTP $\left.\mathrm{kgVS}_{\text {added }^{-1}}\right)$ for assays with glucose addition and butyric acid $\left(B M P=636 \mathrm{LstP} \mathrm{kgVS}_{\text {added }^{-1}}\right)$ for CM16\%S. Neither the production of lactic acid nor of acetic acid could stimulate this increase since they have the same methane potential than glucose. On the other hand, acid hydrolysis of structural carbohydrates may have led to the increase of accessibility of biomass over time, since these polymers are not fully biodegradable in mesophilic AD [37].

In order to better understand the main phenomena occurring during ensiling, and to evaluate the energy conservation of storage trials, measured weight losses were taken into account and BMP related to $\mathrm{VS}_{\text {original }}$ was calculated. The conservation of the initial methane potential is exposed on Table 4 and the evolution of BMPvsoriginal over storage period is presented in Fig. 2. Concerning $\mathrm{CM} 12 \%$, losses were more accentuated for BMP based on VS original. At the end of the experiment, around $37 \%$ of the initial methane potential was lost. Nevertheless, this was an improvement compared to the $46 \%$ of original BMP that was lost after 120 days of fresh cattle manure (13\% of TS content) in our previous work [3]. In this latter study, degradation of structural carbohydrates and VFA was more advanced. The same trend should be expected for CM12\% and so, heavier energy losses should occur for even longer storage periods.

Wheat straw addition was an efficient method to keep the energy potential of the cattle manure. At the end of the 120 days, non-significant losses of BMPvsoriginal occurred for both CM16\% and CM21\%. This demonstrates that the wide formation of side-products (secondary fermentation and proteolysis) had no significant impact on energy preservation.

Regarding co-ensiling assays with glucose, minimal variation of the BMP based on VSoriginal occurred during storage. Only $\mathrm{CM} 12 \% \mathrm{G}$ had a significant decrease of methane potential. After 120 days, original BMP was preserved at $89 \pm 5 \%$ for $\mathrm{CM} 12 \% \mathrm{G}, 96 \pm 2 \%$ for $\mathrm{CM} 16 \% \mathrm{G}$ and $95 \pm 5 \%$ for CM21\%G. The observed increase of BMPvsadded was thus clearly counterbalanced by the VS losses. This means that bio-accessibility of feedstock was not improved enough 
through acid hydrolysis of cellulosic compounds. Furthermore, clostridial fermentation in the last 90 days of $\mathrm{CM} 21 \% \mathrm{G}$ condition had negligible impact on the methane potential of biomass.

Starch addition to cattle manure led to a significant improvement of original methane potential in the early days of ensiling. Indeed, after 15 days, initial BMP increased by $12 \%$ (Table 4). Thus, the biochemical accessibility increased during this period. Since the degradation of structural carbohydrates did not enhance the methane potential for the remaining conditions, this is probably due to the conversion of starch during this period. However, this increase was counterbalanced by the degradation of structural organic matter in the long term. At the end of the storage, full preservation of original BMP (non-significant variation) occurred for CM16\%S.

\subsubsection{BMP distribution in particulate and water-soluble phase}

In the first 30 days of storage, the contribution of the water-soluble phase to the BMP increased for silages without addition of fermentation stimulants (Table $4,4^{\text {th }}$ column). This effect was more important for raw materials with lower TS content. However, in the last 90 days, BMP distribution evolved differently for feedstocks without co-substrates and with only wheat straw addition. For $\mathrm{CM} 12 \%$, water-soluble fraction contributed to $27 \%$ of the total BMP after 30 days of ensiling and decreased to $22 \%$ at the end of the 120 days. This suggests that, during the last 90 days, the loss of water-soluble BMP (due to VFA degradation) was higher than the loss of particulate BMP. In contrast, for $\mathrm{CM} 16 \%$ and $\mathrm{CM} 21 \%$, the contribution of the water-soluble fraction to the BMP kept improving until the end of ensiling. Despite of that, solubilization was less significant than in the first 30 days, due to the reduced fermentation rates after biomass stabilization.

Similarly, the BMP of feedstock with starch was solubilised over storage period, especially in the first week. Indeed, water-soluble fraction contributed to only $8 \%$ of total methane potential before storage and increased to $15 \%$ after 7 days and $22 \%$ at the end of ensiling. This suggests that some starch was quickly hydrolysed.

In contrast, the contribution of the water-soluble fraction to the BMP decreased during ensiling with glucose addition. This was basically observed in first 7 days of storage, during which there was a vast LAB fermentation of glucose. This trend should be related to the yield of WSC that 
was used for bacterial growth. In fact, some data in the literature suggests that the true yield of silage LAB should be of $10-35 \% g_{L A B} / g_{w s c}$ [27]. This would explain why water-soluble contribution to the BMP decreased without being recorded any energy losses during this period.

\section{Conclusions}

Ensiling of single-handedly cattle manure was inefficient for methane potential conservation especially due to the high water availability and to the absence of simple sugars in raw material. A $37 \%$ loss of methane potential occurred after 120 days for this feedstock. The use of sugarrich co-substrates enhanced ensiling performance. Wheat straw addition increased total solids content and stabilized biomass with a pH around 6.0. Reduction of feedstock's moisture through co-ensiling is a favourable method to fully preserve the energy content of fresh cattle manure with minor initial methanogenic activity. In addition, it may avoid technical issues related to the storage of liquid cattle manure in bunker silos. With glucose as co-substrate, extensive heterofermentative LAB fermentation occurred and pH quickly dropped below 4.0. Starch was used as substrate for fermentation but its low hydrolysis limited biomass acidification. Consequently, a WSC-rich co-substrate should be used if lactic preservation of biomass is intended. Despite the different modes of action, all three co-substrates led to minimal methane potential losses after 120 days of storage. Therefore, co-ensiling can be proposed as a valuable solution for energy conservation of cattle manure feedstocks in agricultural biogas plants. In order to be economically viable, co-substrates should be organic wastes or other feedstock planned to be valorised by anaerobic digestion.

\section{Acknowledgements}

Ruben Teixeira Franco held a doctoral fellowship from the Rhône-Alpes region. This work has been undertaken within the SAM project (Stockage Avant Méthanisation - Storage Before AD) funded by ADEME (\# 1506C0038). The authors thank the DEEP laboratory team, including David Lebouil, Hervé Perier-Camby, Nathalie Dumont and Richard Poncet for the given support during the tests. We are grateful to Franck Barra for his permanent availability for discussion and raw material supply. Mathilde Hardier and SUEZ are also acknowledged for the inoculum provided for the BMP tests. 


\section{References}

1. ADEME: French Biomethane Roadmap and Proposed Action Plan for the Period up to 2030. (2013)

2. Berg, W., Pazsiczki, I.: Mitigation of methane emissions during manure storage. Int. Congr. Ser. 1293, 213-216 (2006). doi:10.1016/j.ics.2006.02.050

3. Teixeira Franco, R., Buffière, P., Bayard, R.: Cattle manure for biogas production. Does ensiling and wheat straw addition enhance preservation of biomass and methane potential? Biofuels. (2017). doi:10.1080/17597269.2017.1387751

4. McDonald, P., Henderson, A.., Heron, S.J..: The Biochemistry of Silage. Chalcombe Publications, Marlow, Bucks (1991)

5. Teixeira Franco, R., Buffière, P., Bayard, R.: Ensiling for biogas production: Critical parameters. A review. Biomass and Bioenergy. 94, 94-104 (2016). doi:10.1016/j.biombioe.2016.08.014

6. Herrmann, C., Heiermann, M., Idler, C.: Effects of ensiling, silage additives and storage period on methane formation of biogas crops. Bioresour. Technol. 102, 5153-5161 (2011). doi:10.1016/j.biortech.2011.01.012

7. Kreuger, E., Nges, I., Björnsson, L.: Ensiling of crops for biogas production: effects on methane yield and total solids determination. Biotechnol. Biofuels. 4, 44 (2011). doi:10.1186/1754-6834-4-44

8. Menardo, S., Balsari, P., Tabacco, E., Borreani, G.: Effect of Conservation Time and the Addition of Lactic Acid Bacteria on the Biogas and Methane Production of Corn Stalk Silage. Bioenergy Res. 8, 1810-1823 (2015). doi:10.1007/s12155-015-9637-7

9. Lehtomäki, A.: Biogas Production from Energy Crops and Crop Residues, (2006)

10. Teixeira Franco, R., Buffière, P., Bayard, R.: Optimizing storage of a catch crop before biogas production: impact of ensiling and wilting under unsuitable weather conditions. Biomass and Bioenergy. 100, 84-91 (2017). doi:10.1016/j.biombioe.2017.03.017

11. Teixeira Franco, R., Buffière, P., Bayard, R.: Optimizing agricultural wastes storage before anaerobic digestion : impact of ensiling on methane potential of lignocellulosic biomass. In: 4th International Conference on Sustainable Solid Waste Management. , 
Limassol, Cyprus (2016)

12. Teixeira Franco, R., Buffière, P., Bayard, R.: Co-ensiling of cattle manure before biogas production: effects of fermentation stimulants and inhibitors on biomass and methane preservation. Renew. Energy. (2018)

13. Porter, M.G., Murray, R.S.: The volatility of components of grass silage on oven drying and the inter-relationship between dry-matter content estimated by different analytical methods. Grass Forage Sci. 56, 405-411 (2001). doi:10.1046/j.1365-2494.2001.00292.x

14. Van Soest, P.J., Wine, R.H.: Use of detergents in the analysis of fibrous feeds IV. Determination of plant cell-wall constituents. J. Assoc. Off. Anal. Chem. 50, 50-55 (1967)

15. AFNOR: FD U44-162: Amendements organiques et supports de culture - Caractérisation de la matière organique par fractionnement biochimique et estimation de sa stabilité biologique, (2016)

16. AFNOR: NF EN 25663: Qualité de l'eau - Dosage de l'azote Kjeldahl - Méthode après minéralisation au sélénium, (1994)

17. Holliger, C., Alves, M., Andrade, D., Angelidaki, I., Astals, S., Baier, U., Bougrier, C., Buffiere, P., Carballa, M., de Wilde, V., Ebertseder, F., Fernandez, B., Ficara, E., Fotidis, I., Frigon, J.-C., de Laclos, H.F., Ghasimi, D.S.M., Hack, G., Hartel, M., Heerenklage, J., Horvath, I.S., Jenicek, P., Koch, K., Krautwald, J., Lizasoain, J., Liu, J., Mosberger, L., Nistor, M., Oechsner, H., Oliveira, J. V., Paterson, M., Pauss, A., Pommier, S., Porqueddu, I., Raposo, F., Ribeiro, T., Rusch Pfund, F., Stromberg, S., Torrijos, M., van Eekert, M., van Lier, J., Wedwitschka, H., Wierinck, I.: Towards a standardization of biomethane potential tests. Water Sci. Technol. 74, 2515-2522 (2016). doi:10.2166/wst.2016.336

18. Amer, S., Hassanat, F., Berthiaume, R., Seguin, P., Mustafa, A.F.: Effects of water soluble carbohydrate content on ensiling characteristics, chemical composition and in vitro gas production of forage millet and forage sorghum. Anim. Feed Sci. Technol. 177, 23-29 (2012). doi:10.1016/j.anifeedsci.2012.07.024

19. Haag, N.L., Nägele, H., Fritz, T., Oechsner, H.: Effects of ensiling treatments on lactic 
acid production and supplementary methane formation of maize and amaranth - An advanced green biorefining approach. Bioresour. Technol. 178, 217-225 (2015). doi:10.1016/j.biortech.2014.08.048

20. Kung Jr, L., Ranjit, N.: The Effect of Lactobacillus buchneri and Other Additives on the Fermentation and Aerobic Stability of Barley Silage. J. Dairy Sci. 84, 1149-1155 (2001). doi:10.3168/jds.S0022-0302(01)74575-4

21. Liu, S., Ge, X., Liu, Z., Li, Y.: Effect of harvest date on Arundo donax L. (giant reed) composition, ensilage performance, and enzymatic digestibility. Bioresour. Technol. (2016). doi:10.1016/j.biortech.2016.01.011

22. Pakarinen, A., Maijala, P., Jaakkola, S., Stoddard, F.L., Kymäläinen, M., Viikari, L.: Evaluation of preservation methods for improving biogas production and enzymatic conversion yields of annual crops. Biotechnol. Biofuels. 4, 20 (2011). doi:10.1186/1754$6834-4-20$

23. Pakarinen, O., Lehtoma, A., Rissanen, S., Rintala, J.: Storing energy crops for methane production: Effects of solids content and biological additive. Bioresour. Technol. 99, 7074-7082 (2008). doi:10.1016/j.biortech.2008.01.007

24. Vervaeren, H., Hostyn, K., Ghekiere, G., Willems, B.: Biological ensilage additives as pretreatment for maize to increase the biogas production. Renew. Energy. 35, 20892093 (2010). doi:10.1016/j.renene.2010.02.010

25. Neal, H.D.S.C., Thornley, J.H.M.: A model of the anaerobic phase of ensiling. Grass Forage Sci. 38, 121-134 (1983). doi:10.1111/j.1365-2494.1983.tb01630.x

26. Batstone, D.J., Keller, J., Angelidaki, I., Kalyuzhnyi, S. V., Pavlostathis, S.G., Rozzi, A., Sanders, W.T., Siegrist, H., Vavilin, V.A.: The IWA Anaerobic Digestion Model No 1 (ADM1). Water Sci. Technol. 45, 65-73 (2002). doi:10.2166/wst.2008.678

27. Pitt, R.E., Muck, R.E., Leibensperger, R.Y.: A quantitative model of the ensilage process in lactate silages. Grass Forage Sci. 40, 279-303 (1985). doi:10.1111/j.13652494.1985.tb01755.x

28. Le Hyaric, R., Chardin, C., Benbelkacem, H., Bollon, J., Bayard, R., Escudié, R., Buffière, P.: Influence of substrate concentration and moisture content on the specific 
methanogenic activity of dry mesophilic municipal solid waste digestate spiked with propionate. Bioresour. Technol. 102, 822-827 (2011).

doi:10.1016/j.biortech.2010.08.124

29. Le Hyaric, R., Benbelkacem, H., Bollon, J., Bayard, R., Escudié, R., Buffière, P.: Influence of moisture content on the specific methanogenic activity of dry mesophilic municipal solid waste digestate. J. Chem. Technol. Biotechnol. 87, 1032-1035 (2012). doi:10.1002/jctb.2722

30. Borreani, G., Revello, A., Colombini, S., Odoardi, M., Paoletti, R., Tabacco, E.: Fermentative profiles of field pea (Pisum sativum), faba bean (Vicia faba) and white lupin (Lupinus albus) silages as affected by wilting and inoculation. Anim. Feed Sci. Technol. 151, 316-323 (2009). doi:10.1016/j.anifeedsci.2009.01.020

31. Ren, N., Wang, B., Huang, J.C.: Ethanol-type fermentation from carbohydrate in high rate acidogenic reactor. Biotechnol. Bioeng. 54, 428-433 (1997). doi:10.1002/(SICI)1097-0290(19970605)54:5<428::AID-BIT3>3.0.CO;2-G

32. Mahmoud, S.A.Z., Zaki, M.M., Saleh, E.A.: Factors affecting the microbial and chemical composition of silage: IV. Effect of wilting on maize silage. Zentralblatt fuer Bakteriol. Parasitenkunde, Infekt. und Hyg. Zweite Naturwissenschaftliche Abteilung Mikrobiol. der Landwirtschaft, der Technol. und des Umweltschutzes. 134, 34-39 (1979). doi:10.1016/S0323-6056(79)80061-0

33. Wilkinson, J.M.: A laboratory evaluation of comfrey (Symphytum officinale L.) as a forage crop for ensilage. Anim. Feed Sci. Technol. 104, 227-233 (2003)

34. Dewar, W.A., McDonald, P., Whittenbury, R.: The hydrolysis of grass hemicelluloses during ensilage. J. Sci. Food Agric. 14, 411-417 (1963). doi:10.1002/jsfa.2740140610

35. Van Soest, P.J., Robertson, J.B., Lewis, B.A.: Methods for Dietary Fiber, Neutral Detergent Fiber, and Nonstarch Polysaccharides in Relation to Animal Nutrition. J. Dairy Sci. 74, 3583-3597 (1991). doi:10.3168/jds.S0022-0302(91)78551-2

36. Raposo, F., Fernández-Cegrí, V., de la Rubia, M.A., Borja, R., Béline, F., Cavinato, C., Demirer, G., Fernández, B., Fernández-Polanco, M., Frigon, J.C., Ganesh, R., Kaparaju, P., Koubova, J., Méndez, R., Menin, G., Peene, A., Scherer, P., Torrijos, M., Uellendahl, 
H., Wierinck, I., de Wilde, V.: Biochemical methane potential (BMP) of solid organic substrates: Evaluation of anaerobic biodegradability using data from an international interlaboratory study. J. Chem. Technol. Biotechnol. 86, 1088-1098 (2011). doi:10.1002/jctb.2622

37. Ghosh, S., Henry, M.P., Christopher, R.W.: Hemicellulose conversion by anaerobic digestion. Biomass. 6, 257-269 (1985). doi:10.1016/0144-4565(85)90052-6 
Table 1 Ensiling conditions and treatments applied to cattle manure. Each duration corresponds to a single silo (sacrificed and opened for analysis after $x$ days)

\begin{tabular}{|c|c|c|c|c|c|c|}
\hline \multirow{2}{*}{ Condition } & \multirow{2}{*}{ Duration (days) } & \multicolumn{3}{|c|}{ Co-substrate } & \multirow{2}{*}{ TS (\%) ${ }^{b}$} & \multirow{2}{*}{ VS (\%) ${ }^{b}$} \\
\hline & & Wheat straw ${ }^{a}$ & Glucose $^{a}$ & Starch a & & \\
\hline CM12\% & $30 ; 120$ & - & - & - & $11.6 \pm 0.1$ & $9.50 \pm 0.12$ \\
\hline CM16\% & $30 ; 120$ & $7.0 \%$ & - & - & $16.3 \pm 0.4$ & $14.2 \pm 0.4$ \\
\hline CM21\% & $30 ; 120$ & $15.3 \%$ & - & - & $20.9 \pm 1.2$ & $18.6 \pm 1.2$ \\
\hline CM12\%G & $7 ; 15 ; 30 ; 120$ & - & $10.0 \%$ & - & $10.3 \pm 0.3$ & $9.04 \pm 0.21$ \\
\hline CM16\%G & $7 ; 15 ; 30 ; 120$ & $7.0 \%$ & $10.0 \%$ & - & $15.3 \pm 0.3$ & $14.0 \pm 0.3$ \\
\hline CM21\%G & $7 ; 15 ; 30 ; 120$ & $15.3 \%$ & $10.0 \%$ & - & $19.8 \pm 0.5$ & $18.2 \pm 0.4$ \\
\hline CM16\%S & $7 ; 15 ; 30 ; 120$ & $7.0 \%$ & - & $5.3 \%$ & $20.4 \pm 0.1$ & $18.4 \pm 0.1$ \\
\hline
\end{tabular}

Results presented as wt. $\%$ of: ${ }^{a}$ cattle manure; ${ }^{b}$ feedstock 
Table 2 Fermentation profiles of biomass over ensiling duration (\%VS added/original unless otherwise specified)

\begin{tabular}{|c|c|c|c|c|c|c|c|c|c|c|}
\hline Condition & $\begin{array}{c}\text { Duration } \\
\text { (days) }\end{array}$ & $\mathrm{pH}$ & WSC $^{a}$ & $\mathbf{L A}^{\mathrm{a}}$ & $\mathbf{A A}^{\mathrm{a}}$ & $\mathbf{B A}^{\mathrm{a}}$ & VFA $^{a}$ & Ethanol $^{\mathrm{a}}$ & $\begin{array}{c}\mathbf{N H}_{3}-\mathbf{N} \\
(\% T K N)\end{array}$ & TKN $^{b}$ \\
\hline & 0 & 7.7 & - & - & 3.6 & 0.2 & 5.0 & - & 20.8 & 3.2 \\
\hline \multirow[t]{3}{*}{ CM12\% } & 30 & 6.1 & 0.1 & - & 9.9 & 1.5 & 14.1 & - & 37.7 & 3.4 \\
\hline & 120 & 7.8 & 0.2 & - & 4.5 & 0.5 & 8.3 & - & 41.7 & 3.0 \\
\hline & 0 & 8.1 & - & - & 1.9 & - & 2.5 & - & 21.5 & 1.9 \\
\hline \multirow[t]{3}{*}{ CM16\% } & 30 & 5.9 & - & - & 6.3 & 1.0 & 9.0 & - & 30.3 & 2.3 \\
\hline & 120 & 5.9 & 0.1 & - & 7.1 & 1.7 & 11.7 & - & 33.8 & 2.4 \\
\hline & 0 & 8.1 & - & - & 1.4 & - & 1.8 & - & 14.8 & 1.3 \\
\hline \multirow[t]{4}{*}{ CM21\% } & 30 & 6.0 & - & - & 4.6 & 1.0 & 6.7 & - & 28.2 & 1.8 \\
\hline & 120 & 6.0 & 0.1 & - & 5.6 & 1.5 & 9.3 & - & 33.2 & 1.7 \\
\hline & 0 & 7.4 & 52.6 & 0.1 & 2.4 & - & 2.9 & - & 20.7 & 1.6 \\
\hline & 7 & 3.8 & 25.6 & 17.1 & 3.0 & - & 20.7 & 4.9 & 18.7 & 1.6 \\
\hline \multirow[t]{5}{*}{ CM12\%G } & 15 & 3.6 & - & 23.7 & 3.3 & 0.3 & 27.8 & 13.9 & 18.3 & 1.5 \\
\hline & 30 & 3.6 & 0.1 & 24.2 & 3.8 & - & 28.0 & 16.6 & 18.8 & 1.5 \\
\hline & 120 & 3.8 & 0.2 & 17.4 & 6.9 & 0.4 & 25.8 & 16.6 & 19.7 & 1.5 \\
\hline & 0 & 7.6 & 40.5 & - & 1.8 & - & 1.8 & - & 21.1 & 1.1 \\
\hline & 7 & 4.4 & 9.5 & 13.9 & 2.1 & - & 16.5 & 4.6 & 17.6 & 1.2 \\
\hline \multirow[t]{5}{*}{ CM16\%G } & 15 & 3.7 & 0.7 & 17.5 & 2.2 & 0.2 & 20.3 & 10.0 & 16.9 & 1.2 \\
\hline & 30 & 3.6 & 0.1 & 18.4 & 2.5 & - & 20.8 & 11.4 & 16.4 & 1.2 \\
\hline & 120 & 3.6 & 0.1 & 16.4 & 3.3 & - & 20.2 & 11.8 & 15.9 & 1.3 \\
\hline & 0 & 7.6 & 35.6 & - & 1.5 & - & 1.6 & - & 20.1 & 0.9 \\
\hline & 7 & 4.6 & 9.2 & 12.9 & 1.7 & - & 14.9 & 5.8 & 17.1 & 1.0 \\
\hline \multirow[t]{5}{*}{ CM21\%G } & 15 & 3.8 & - & 13.2 & 1.7 & 0.6 & 15.7 & 9.5 & 15.7 & 1.1 \\
\hline & 30 & 3.9 & 0.1 & 13.0 & - & - & 13.0 & 10.2 & 16.8 & 1.1 \\
\hline & 120 & 5.0 & - & - & 2.0 & 5.8 & 11.2 & 10.3 & 22.6 & 1.1 \\
\hline & 0 & 7.9 & - & - & 1.6 & - & 2.1 & - & 15.8 & 1.6 \\
\hline & 7 & 5.5 & - & 1.3 & 3.8 & 2.1 & 8.2 & 0.3 & 14.8 & 1.7 \\
\hline \multirow[t]{3}{*}{ CM16\%S } & 15 & 5.1 & - & - & 3.7 & 3.0 & 7.9 & 0.3 & 16.7 & 1.7 \\
\hline & 30 & 5.6 & 0.1 & - & 4.9 & 4.6 & 11.6 & - & 18.5 & 1.6 \\
\hline & 120 & 4.8 & 0.1 & - & 5.5 & 5.0 & 13.9 & 0.4 & 21.3 & 1.6 \\
\hline
\end{tabular}

WSC stands for Water Soluble Carbohydrates, LA for Lactic Acid, AA for Acetic Acid, BA for Butyric Acid, VFA for Volatile Fatty Acids, $\mathrm{NH}_{3}-\mathrm{N}$ for Ammonia Nitrogen and TKN for Total Kjeldahl Nitrogen; ${ }^{a}$ results based on \%VS added; ${ }^{b}$ results based on $\% V_{\text {original }}$ 
Table 3 Impact of ensiling period and co-substrates on fibres composition of cattle manure (\%VS original)

\begin{tabular}{|c|c|c|c|c|}
\hline Condition & Duration (days) & Hemicelluloses & Cellulose & Lignin \\
\hline & 0 & $28.4 \pm 1.1$ & $25.7 \pm 1.4$ & $8.5 \pm 0.3$ \\
\hline \multirow[t]{2}{*}{ CM12\% } & 30 & $21.7 \pm 0.6$ & $19.3 \pm 1.8$ & $8.9 \pm 0.7$ \\
\hline & 120 & $16.6 \pm 0.5$ & $15.9 \pm 1.2$ & $7.9 \pm 0.5$ \\
\hline & 0 & $31.1 \pm 0.5$ & $36.8 \pm 1.5$ & $7.4 \pm 0.19$ \\
\hline \multirow{2}{*}{ CM16\% } & 30 & $25.5 \pm 1.3$ & $26.3 \pm 2.6$ & $9.5 \pm 0.5$ \\
\hline & 120 & $25.0 \pm 0.19$ & $22.5 \pm 0.20$ & $10.1 \pm 0.07$ \\
\hline \multirow{3}{*}{ CM21\% } & 0 & $35.7 \pm 0.8$ & $42.6 \pm 1.5$ & $8.4 \pm 0.15$ \\
\hline & 30 & $29.9 \pm 0.9$ & $34.2 \pm 2.0$ & $8.2 \pm 0.24$ \\
\hline & 120 & $27.6 \pm 0.3$ & $27.6 \pm 7.6$ & $9.7 \pm 2.6$ \\
\hline \multirow{5}{*}{ CM12\%G } & 0 & $13.7 \pm 0.4$ & $13.5 \pm 0.8$ & $3.5 \pm 0.16$ \\
\hline & 7 & $12.5 \pm 1.2$ & $12.2 \pm 2.0$ & $3.2 \pm 0.23$ \\
\hline & 15 & $13.0 \pm 0.22$ & $13.0 \pm 0.5$ & $3.0 \pm 0.10$ \\
\hline & 30 & $11.7 \pm 0.3$ & $12.3 \pm 0.4$ & $2.9 \pm 0.03$ \\
\hline & 120 & $11.6 \pm 0.09$ & $11.5 \pm 2.5$ & $3.7 \pm 0.8$ \\
\hline \multirow{5}{*}{ CM16\%G } & 0 & $18.5 \pm 0.5$ & $22.0 \pm 0.6$ & $4.4 \pm 0.09$ \\
\hline & 7 & $16.2 \pm 0.24$ & $18.8 \pm 1.0$ & $3.7 \pm 0.16$ \\
\hline & 15 & $17.1 \pm 0.4$ & $20.1 \pm 0.6$ & $4.2 \pm 0.10$ \\
\hline & 30 & $17.1 \pm 0.4$ & $18.8 \pm 1.1$ & $4.3 \pm 0.19$ \\
\hline & 120 & $16.2 \pm 0.3$ & $15.0 \pm 1.5$ & $6.7 \pm 0.6$ \\
\hline \multirow{5}{*}{ CM21\%G } & 0 & $21.6 \pm 0.20$ & $25.5 \pm 2.0$ & $4.8 \pm 0.3$ \\
\hline & 7 & $19.8 \pm 0.5$ & $22.4 \pm 1.4$ & $4.5 \pm 0.24$ \\
\hline & 15 & $20.7 \pm 0.5$ & $21.7 \pm 1.4$ & $6.1 \pm 0.3$ \\
\hline & 30 & $21.7 \pm 0.4$ & $24.3 \pm 1.2$ & $5.0 \pm 0.21$ \\
\hline & 120 & $21.4 \pm 0.4$ & $20.7 \pm 1.6$ & $7.0 \pm 0.13$ \\
\hline \multirow{5}{*}{ CM16\%S } & 0 & $28.0 \pm 0.8$ & $32.8 \pm 3.2$ & $9.2 \pm 0.9$ \\
\hline & 7 & $23.0 \pm 0.4$ & $23.0 \pm 0.3$ & $7.3 \pm 0.06$ \\
\hline & 15 & $23.6 \pm 0.8$ & $23.6 \pm 2.9$ & $8.0 \pm 0.7$ \\
\hline & 30 & $24.8 \pm 1.0$ & $23.8 \pm 1.8$ & $5.6 \pm 0.24$ \\
\hline & 120 & $24.2 \pm 0.21$ & $22.9 \pm 1.4$ & $4.8 \pm 0.3$ \\
\hline
\end{tabular}


Table 4 BMP based on VSadded, its water-soluble fraction and energy conservation over storage period

\begin{tabular}{|c|c|c|c|c|}
\hline Condition & $\begin{array}{l}\text { Duration } \\
\text { (days) }\end{array}$ & $\begin{array}{l}\text { BMP (LstP } \\
\left.\text { kgVS }_{\text {added }^{-1}}\right)\end{array}$ & $\begin{array}{l}\text { BMP }_{\text {water-soluble fraction }} \\
\text { (\%BMP crude material) }\end{array}$ & $\begin{array}{l}\text { Conservation of } \\
\text { original BMP (\%) }\end{array}$ \\
\hline & 0 & $257 \pm 6$ & $17 \pm 1.8$ & - \\
\hline \multirow[t]{2}{*}{ CM12\% } & 30 & $237 \pm 15$ & $27 \pm 1.9$ & $86 \pm 9$ \\
\hline & 120 & $217 \pm 2.0$ & $22 \pm 0.7$ & $63 \pm 3$ \\
\hline & 0 & $232 \pm 5$ & $11 \pm 0.6$ & - \\
\hline \multirow[t]{2}{*}{ CM16\% } & 30 & $196 \pm 4$ & $18 \pm 0.8$ & $81 \pm 4$ \\
\hline & 120 & $234 \pm 4$ & $21 \pm 0.8$ & $95 \pm 4$ \\
\hline \multirow{3}{*}{ CM21\% } & 0 & $215 \pm 4$ & $8 \pm 0.7$ & - \\
\hline & 30 & $186 \pm 1.9$ & $13 \pm 4$ & $84 \pm 3$ \\
\hline & 120 & $228 \pm 12$ & $16 \pm 1.3$ & $101 \pm 7$ \\
\hline \multirow{5}{*}{ CM12\%G } & 0 & $319 \pm 9$ & $54 \pm 4$ & - \\
\hline & 7 & $328 \pm 2.0$ & $46 \pm 1.4$ & $98 \pm 3$ \\
\hline & 15 & $347 \pm 8$ & $46 \pm 3$ & $94 \pm 5$ \\
\hline & 30 & $306 \pm 9$ & $49 \pm 2.2$ & $82 \pm 6$ \\
\hline & 120 & $341 \pm 8$ & $50 \pm 3$ & $89 \pm 5$ \\
\hline \multirow{5}{*}{ CM16\%G } & 0 & $286 \pm 3$ & $42 \pm 1.4$ & - \\
\hline & 7 & $298 \pm 7$ & $37 \pm 2.2$ & $100 \pm 3$ \\
\hline & 15 & $339 \pm 11$ & $33 \pm 3$ & $106 \pm 4$ \\
\hline & 30 & $265 \pm 2$ & $36 \pm 1.7$ & $83 \pm 2$ \\
\hline & 120 & $312 \pm 3$ & $38 \pm 1.5$ & $96 \pm 2$ \\
\hline \multirow{5}{*}{ CM21\%G } & 0 & $271 \pm 10$ & $37 \pm 4$ & - \\
\hline & 7 & $294 \pm 13$ & $31 \pm 3$ & $102 \pm 8$ \\
\hline & 15 & $318 \pm 7$ & $29 \pm 1.9$ & $105 \pm 6$ \\
\hline & 30 & $244 \pm 6$ & $28 \pm 2.4$ & $80 \pm 6$ \\
\hline & 120 & $307 \pm 9$ & $28 \pm 1.6$ & $95 \pm 6$ \\
\hline \multirow{5}{*}{ CM16\%S } & 0 & $236 \pm 5$ & $8 \pm 1.9$ & \\
\hline & 7 & $264 \pm 9$ & $15 \pm 0.8$ & $108 \pm 5$ \\
\hline & 15 & $275 \pm 7$ & $15 \pm 1.7$ & $112 \pm 5$ \\
\hline & 30 & $210 \pm 7$ & $18 \pm 1.1$ & $83 \pm 5$ \\
\hline & 120 & $254 \pm 7$ & $22 \pm 1.8$ & $98 \pm 5$ \\
\hline
\end{tabular}


(a)

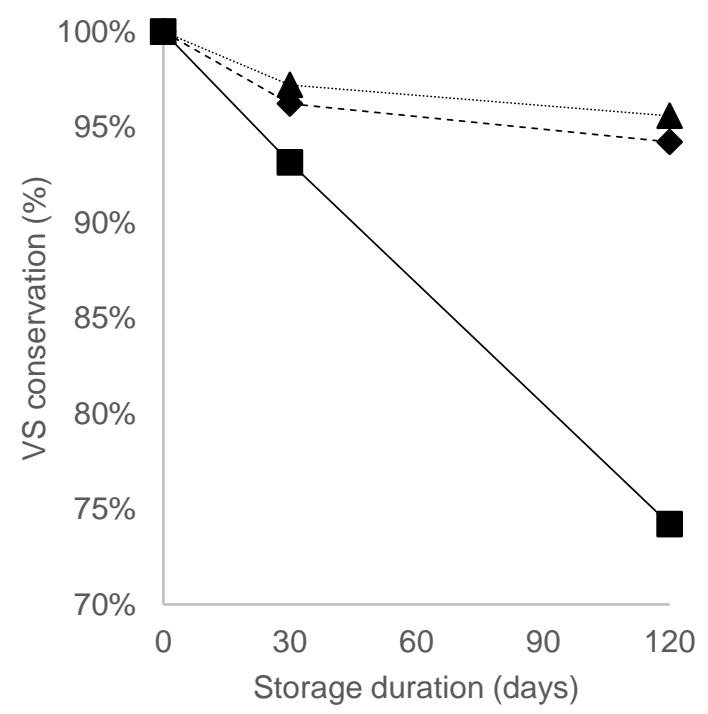

$\longrightarrow$ CM12\% - - CM16\% ................ CM21\% (b)

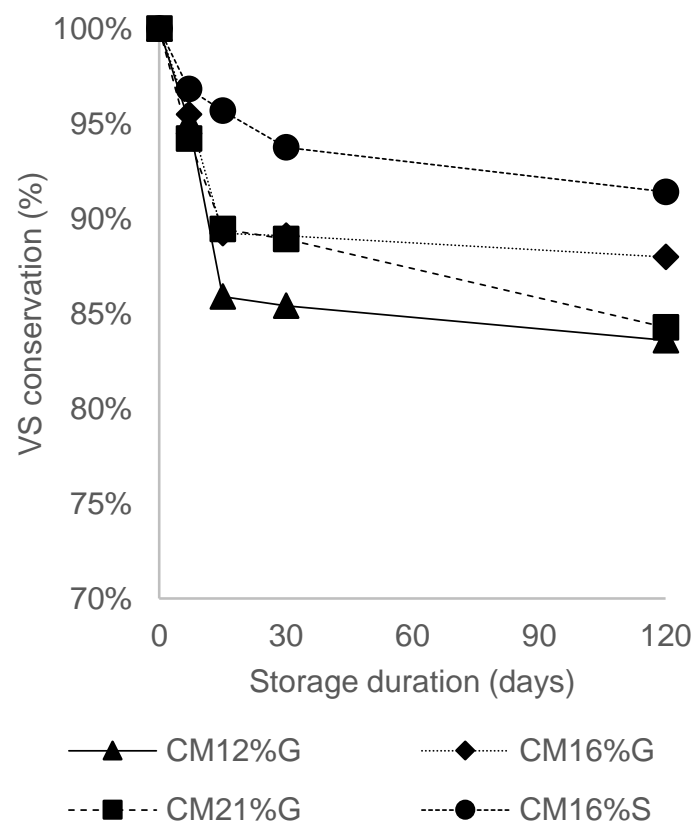

Fig. 1 Preservation of organic matter over storage duration. (a): effects of wheat straw addition; (b): co-ensiling conditions with glucose and starch 
(a)

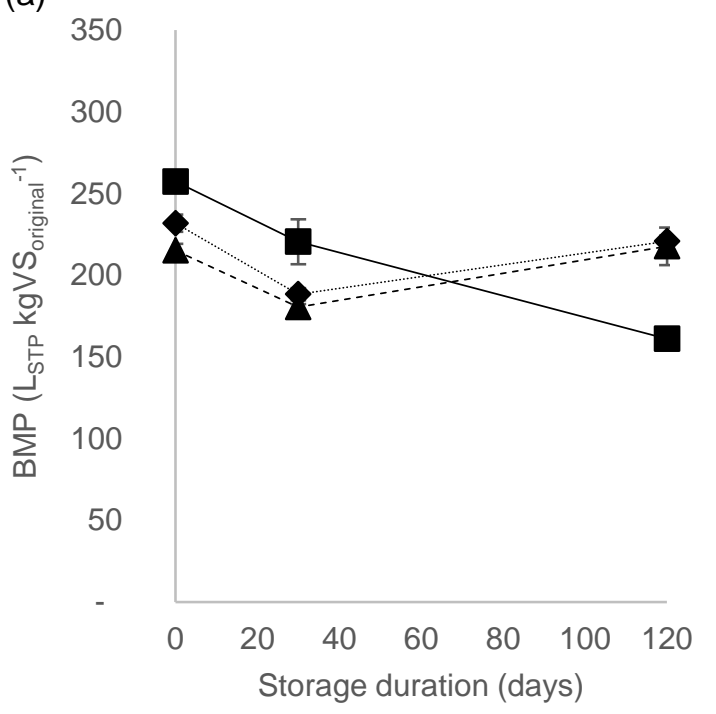

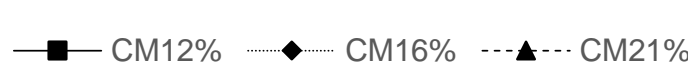

(b)

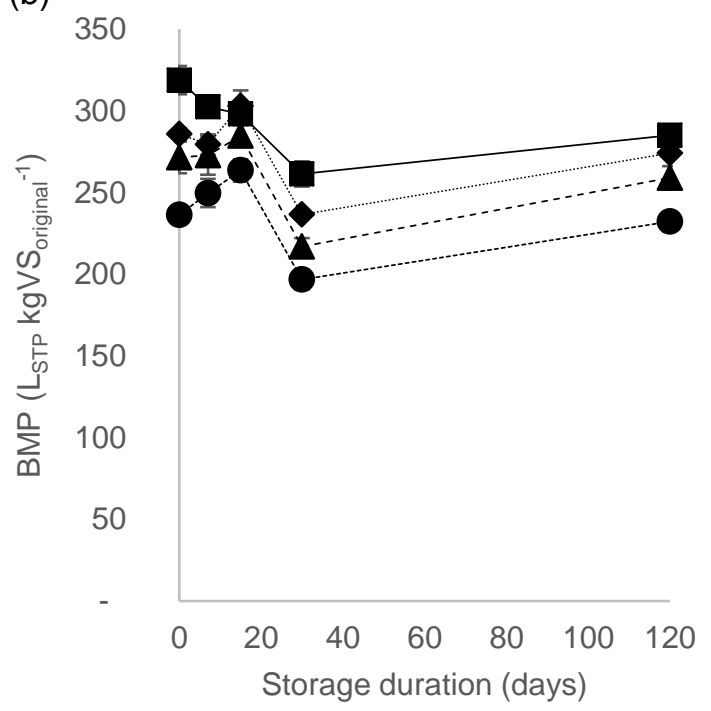

$\rightarrow-\mathrm{CM} 12 \% \mathrm{G}$

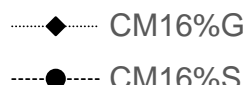

Fig. 2 BMP evolution of crude material over storage duration. (a): effects of wheat straw addition; (b): co-ensiling conditions with glucose and starch. Methane potential is based on VSoriginal, therefore considering VS losses during storage 